\title{
Marine Animals: the Next Generation of Autonomous Underwater Vehicle?
}

\author{
T. M. Thys \\ Sea Studios Foundation, 810 Cannery Row \\ Monterey CA, 93940 tierney@mbay.net \\ B. W. Hobson \\ Nekton Research, LLC. 4625 Industry Lane \\ Durham NC 27713 b.hobson@ nektonresearch.com \\ H. Dewar \\ Pfleger Institute of Environmental Science, 1400 N. Pacific St. \\ Oceanside, CA 92054 Heidi_Dewar@alumni.ucsd.edu
}

\begin{abstract}
Advances in animal tag technologies now offer a significant method for gathering oceanographic information throughout the world's oceans. By employing marine organisms as oceanic samplers (MOOS), vast amounts of in situ data (e.g. temperature, productivity and salinity in relation to depth and location) can be archived and transmitted via satellite or obtained directly from the tag if the tag is recovered. The beauty of this technique is that no on-board navigation system nor external propulsion supply is required. The animal performs the work necessary to transport the equipment and chooses what transect to run. The gathered data, guided by the animal's point of view, reveal secrets of the animal's life and pinpoint environmental features most important to its lifestyle. Depending on the species tagged, the animal may perform a number of tasks of great interest to oceanographers e.g. gathering data from remote regions like the poles, performing repeated deep dives, targeting specific food sources or oceanographic features and traversing massive expanses of ocean. The breadth of animal species with which this technology has been successfully deployed is growing steadily. The list includes bluefin and yellowfin tuna, white sharks, thresher sharks, whale sharks, ocean sunfish, marine turtles, seals, sea lions, and seabirds. It is hoped that the wealth of tag data already being collected worldwide can serve both the needs of the biologic and oceanographic communities alike.
\end{abstract}

\section{Introduction}

Is the temperature of the ocean rising? What are the pathways of pollutants? When will the next El Niño occur? Can we collect sufficient data to validate ocean circulation models that can predict future direction of climate change? Never has the need to address such pressing environmental questions been more vital than it is today.

Confronting such complex issues requires a massive system of accurate global environmental monitoring. Increasingly sophisticated remote sensing technology offers a number of promising approaches. For example:

- Passive probes gather data along ocean current corridors. Drifting at the mercy of the currents, probes periodically perform descents and surface at programmed intervals. The data and geolocation are then uploaded via the satellite communications network to create profiles and infer subsurface currents. These passive probes can last upwards of five years. Examples include: APEX, ALACE and ARGO.*

- Geostationary and polar environmental orbiting satellites (POES), equipped with imaging devices, create detailed pictures of sea surface temperature, chlorophyll/ productivity levels (e.g. SeaWiFS, AVHRR, MODIS) plus sea surface height (e.g.TOPEX/POSEIDON).

- Moored weather buoys, like those of NOAA's NDBC, gather data on currents, temperature and conductivity from stationary locations.

- Ships of opportunity equipped with hullmounted instruments can gather oceanic data along their set trajectories [1].

While the amount of data being collected, especially via satellite imagery, is staggering, devising cost-effective means for ground-truthing, particularly in remote regions, remains a challenge. Autonomous underwater vehicles (AUVs) e.g. Webb Research Corporation's Slocum Glider, Southhampton Oceanography Centre's Autosub, Bluefin Robotic's Odyssey line and Wood's Hole Oceanographic Institute's $A B E$ and REMUS offer promise yet remain relatively expensive and somewhat limited in their endurance. Of note in endurance however is ISE Research Ltd.'s AUV

\footnotetext{
All acronyms are defined in the Appendix.
} 
Theseus that performed a successful $405 \mathrm{~km}$ run in British Columbia, Canada in January, 1996 [2].

Imagine however if a massive network of ocean-going vehicles existed that could: (1) carry a multitude of oceanographic equipment (2) travel across a large range of distances, depths and currents worldwide, (3) pinpoint salient oceanic features and food supplies (4) journey through all manner of weather and best of all (5) require no battery power or on-board navigation systems. Such a network already exists and can be found in the form of pelagic marine animals. Employing marine organisms as oceanic samplers, hereby referred to as MOOS, comes with its own set of unique challenges. Advances in animal tag technology, however, are increasing the potential of this technique and opening exciting avenues for both biologists and oceanographers.

\section{Tagging Technology}

In an effort to understand the lives of open ocean animals, biologists and engineers have joined forces to develop a variety of increasingly reliable and robust animal tags equipped with diverse capabilities. For a review see Arnold and Dewar, in press [3]. These tags fall into three basic groups: acoustic telemetry tags, satellite tags, and archival tags with and without satellite uplink capability. Each type of tag has its own particular strengths and limitations with regard to its capacities and deployment logistics. Identifying which tag technology is best suited for a particular question depends largely on the required sampling interval and data resolution as well as the needed precision and accuracy of location estimates. These features vary greatly across the different tagging technologies.

\section{- Acoustic Telemetry: Active Tracking and Listening Stations}

Acoustic telemetry, first implemented in the 1950s, is the oldest method of the electronic tag employed for studying movements of marine organisms [4]. This technology can be employed through two different strategies-active tracking or fixed listening stations [5].

\section{Active Tracking}

In active tracking, a device is attached to the animal that records and transmits data from environmental and/or physiological sensors. The transmitted data are then received by a hydrophone secured to a vessel that must closely follow the animal. Dependent on conditions, these tags can transmit signals from an animal to a hydrophone up to 1 nautical mile away [6]. The transmitted data, e.g. real-time depth, temperature, and salinity, can then be cross-correlated with data collected from ship-deployed probes and sonar systems to determine regional patterns in both physical and biological variables. The location of the animal is tracked in real-time and can be determined within tens of meters. New systems, presently under development, will allow greater precision and accuracy. Leading manufacturers for acoustic telemetry tags include LOTEK Wireless Inc.[7] and VEMCO Ltd. [8].

\section{Listening Stations}

Listening stations operate in a similar manner but in lieu of actively tracking the animal, hydrophones are fixed to likely stationary way points along the animals' predicted trajectory. The receivers gather data from the tagged organisms as they pass nearby. Most receivers currently in use are relatively simple and record only an identification code and a limited amount of data. Systems, under development, will be able to uplink data stored by a hybrid acoustic/archival tag.

\section{Benefits}

Acoustic telemetry provides very highresolution data $(1 \mathrm{~Hz}$ being a typical sampling frequency) and location estimates on the order of tens of meters. Additionally this method can accommodate sampling from a wide variety of physical parameters. Hypothetically, as long as the sensor size is conducive to the size of your study organism, it should be possible to incorporate any sensor that generates an electrical signal into an acoustic tag. In the case of listening stations, there is no need to follow the fish and both the temporal and spatial scale of coverage can be large. 


\section{Drawbacks}

The limitation of this technique is that due to the relatively high expense of vessel time and the labor-intensive nature of tracking, tracks tend to be on the order of days instead of months or years. Hence this technique is not cost-effective for examining large-scale patterns. Also, it is only possible to actively follow one individual at a time, a drawback that limits the potential sample size. For listening stations, the rates and types of data that can be obtained are currently limited.

\section{- Archival Tags}

As the name suggests, archival tags archive data. Archival tags must be recovered in order to obtain the data and thus are best suited for species with high recovery rates $e$.g. commercially targeted species and marine mammals that reliably return to shore. These devices are either implanted or secured externally where they sample and record data. With advances in both hardware and software, these tags are increasingly sophisticated and smaller in size. For example, tags used for bluefin tuna (approx. $6 \mathrm{~cm}$ ) can log depth, internal and ambient temperature and light levels every two mins for two years before the memory fills. Much smaller tags are presently in development. Manufacturers include Wildlife Computers Inc. and LOTEK Wireless Inc.

As with acoustic telemetry, a large number of variables can be measured and recorded simultaneously including, compass heading, sound, heart rate, temperature, and light levels [9]. Location of the MOOS is generally determined using relative changes in light levels to determine the time of sunrise, sunset and local noon. Established algorithms allow calculation of latitude from day length and longitude from time of local noon. These tags are equipped with a real-time clock to enable these calculations. Longitude can be calculated within approximately 0.3 degrees [10]. The error in latitude increases near the equator and latitude cannot be determined around the equinox. Generally, however, errors are considered to be less that 2 degrees [11]. Fortunately, error estimates can be dramatically improved by crosschecking sea surface temperature from the tag with AVHRR sea surface temperature imagery.

One method used to dramatically improve location estimates for organisms that surface regularly is via a GPS receiver. Such receivers can compute geographic position within 1-2 m with a frequency every few minutes using relatively small equipment and low power consumption. A prototype tag called TrackTag ${ }^{\text {TM }}$ currently under development measures $7 \mathrm{~cm} \times 7 \mathrm{~cm} \mathrm{x} 1 \mathrm{~cm}$ and weighs $25 \mathrm{~g}$ in air. The TrackTag ${ }^{\text {TM }}$ low power consumption is possible due to a patented NAVSYS GPS technology that stores the raw GPS data to non-volatile memory and thus avoids power costly on-board computations of GPS position (www.navsys.com/tracktag.htm).

\section{Benefits}

The advantages of archival tags lie in (1) their ability to record and store large amounts of data from multiple sensors and (2) their small, less obtrusive size owing to the fact that no extra batteries for transmission are required.

\section{Drawbacks}

As stated previously, in order to retrieve data, the tag must be recovered. As such a large number of tags must be deployed to insure adequate recapture rates and/or tag deployment must be relegated to those species with a high likelihood of return e.g. animals with homing behavior and low mortality rates like marine mammals [12] or marine turtles [13]. Also, the resolution of location estimates is limited.

\section{- Satellite tags: Real-time Uplink and Pop-off Satellite Archival Tags (PSAT)}

\section{Real-Time Uplink Satellite Tagging}

These satellite tags provide real-time uplink capability with the added benefit of never having to follow or relocate the tagged animal. These tags are either secured to fur, a fin or are incorporated into a buoyant tow body. The substantial battery requirements associated with transmission make them relatively large in size especially those incorporated into a tow body. (The tags used by 
Eckert and Stewart (2001) to tag whale sharks were $42 \mathrm{~cm}$ in length [14].) Data are logged and immediately transmitted to satellite each time the tag antenna breaks the surface. The tags record more data than can be presently transmitted via the satellite system. Hence the data must be highly compressed. Depth records are, for example, compressed into histograms. These devices have been used successfully to track a variety of marine mammals and sharks. Leading manufacturers include LOTEK Wireless Inc., Wildlife Computers, Telonics, Sirtrack and Microwave Telemetry.

\section{Benefits}

The primary advantage of the real-time uplink satellite tags is that the location estimates obtained from ARGOS have much higher resolution (on the order of meters) than light-based geolocation estimates. Also, no recovery of the tag is required, since data are relayed in real-time via satellite uplink.

\section{Drawbacks}

Compression of transmitted data leads to some loss of information. However if the tag is recovered, all data can be retrieved. Also the relatively large tag size limits the number of species that can be conscientiously and effectively employed. Individuals over 2 meters in length typically work the best. However, ongoing efforts to miniaturize sensors along with incorporating micro fuel-cells as power supplies will work towards decreasing both size and eventually cost of these tags.

\section{Pop-off Satellite Archival Tagging}

Pop-off Satellite Archival Tags (PSATs) are considerably smaller than real-time satellite tags $(42 \mathrm{~cm}$ to $15 \mathrm{~cm}$ ) and are proving to be a versatile, economical option for tagging a wide variety of open ocean animals [15]. Although PSATs do not provide real-time uplink capacity, they do offer some added flexibility. The tagged animal never needs to break the surface to relay the data. Data are collected and stored throughout the tag's deployment and only transmitted after the tag releases from the animal at a predetermined time and floats to the surface. Tags provide data on daily geolocation, environmental temperature, and depth. Like in the towed satellite tags, data are highly compressed when sent to satellite. Leading manufacturers include Microwave Telemetry and Wildlife Computers Inc.

\section{Benefits}

Since the data are relayed to satellite, no recovery of the tag is required. Furthermore the small size and relative non-invasiveness of the tags have increased the number of species that can serve as MOOS. PSATs have been successfully deployed on a growing number of species including: bluefin tuna [16], white sharks [17], thresher sharks [18], whale sharks [19], ocean sunfish [20], marine turtles [21], whales [22], seals [23], sea lions [24], and seabirds [25].

\section{Drawbacks}

Similar to the towed satellite tags, compression of the transmitted data leads to considerable loss of information. However if the tag is recovered, all data can be retrieved. Also, as with the archival tags, light based geolocation has limited resolution.

\section{- Planned Improvements}

A number of ongoing improvements promise to increase the availability, accuracy and amount of MOOS data. These include: (1) built-in safeguards, like mechanisms that release the tag in response to unsafe dive depths and periods of extended animal immobility (2) continued miniaturization of sensors and power supplies that will lead to smaller tags and a greater size range and variety of potential MOOS (3) development of smarter software that will help conserve the life of the battery. Examples in this third category include software that tells tags to transmit only when the satellite is overhead as well as software that instructs the tag to record only noteworthy data e.g. only inflection points are recorded during a dive [26].

Additional improvements to the satellite system are currently underway. ARGOS plans to increase the amount of data that can be uplinked per transmission. The current rate is only 31 Bytes per uplink. Also, a newly developed two-way 
communication system should ultimately reduce the number of wasted transmissions by coordinating transmission between the tag and the satellite. As both the low earth orbiting satellites and the satellite phone technology improve, the tags should ultimately function much like a cell phone, dramatically increasing the rates of data transfer. MOOS phone home.

\section{Choosing the right MOOS for you}

As more tag information becomes available and the intricate peregrinations of marine pelagic fauna are revealed worldwide, a greater diversity of MOOS should avail themselves to the oceanographic community. Deciding which tagging technology and MOOS to choose will depend on the question at hand. Below, we present a random handful of scenarios:

- For collecting data along the California Current from the Southern California Bight up to Oregon, Washington and British Columbia, sea lions Zalophus californianus may offer a useful platform for transporting oceanographic equipment [27].

- For examining the character of the Gulf Stream either bluefin tuna Thunnus thynnus $L$. or blue sharks Prionace glauca could provide valuable information [28].

- For performing coastal transects from Baja California to the Bering Sea, equipping a migrating gray whale Eschrichtius robustus with oceanographic sensors could prove a costeffective option [29].

- For locating and characterizing sea mounts, hammerhead sharks could be serve as the ideal escort [30].

- For performing multiple dives and securing numerous time/ temperature /depth profiles, elephant seals Mirounga angustirostris who routinely dive to $600 \mathrm{~m}$ with short surface intervals (1-3 min) may provide the perfect platform [31].
Recently Boehlert et al. [32] entered into NOAA's World Ocean Database (WOD) substantial amounts of data acquired by northern elephant seals Mirounga angustirostris in central California. These animals were instrumented with time-temperature-depth recorders (TTDRs) and platform terminal transmitters. Temperature and depth were measured and stored every $30 \mathrm{sec}$ and retrieved after the animals returned to the rookery months later. Mean dive duration was $20 \mathrm{~min}$ and mean dive depth was $428 \mathrm{~m}$. A comparison of temperature profiles from seal TTDR and GTSPP subsurface data showed very good agreement as did the surface temperature to other sources of SST. A total of 75,665 profiles, labeled autonomous pinniped bathythermograph (APBT) profiles, over $41,702 \mathrm{~km}$ of seal trackline were added to NOAA's WOD. While an XBT cost upwards of $\$ 60$ each plus boat and other expenses, an APBT with ARGOS fix costs only \$34.31 [33]. Boehlert et al. (2001) demonstrate the costeffective feasibility of incorporating MOOS data into the oceanographic data stream for regions of the ocean that are sparsely sampled.

The number of research programs employing PSATs and other types of animal tag technology is rapidly growing. In 1998 alone, 11,800 animal tags were deployed [34]. One significant upcoming developing is the Census of Marine Life (www.coml.org) which is slated to tag hundreds of animal species and thousands of individuals by 2010.

\section{Considerations}

For MOOS data to become truly integrated into the oceanographic data stream, two factors must be considered: firstly, present geolocation estimates must be improved. Resolution of all gathered data must continue to improve in order to comply with the quality standards needed for such organizations as GOOS (Global Ocean Observing System), CLIVAR (Climate Variability and Predictability) and OBIS (Ocean Biogeographic Information System). Other data gathering organizations include GCOS, GLOBEC, JGOFS, NOPP and GODAE. Secondly, open highways of

\footnotetext{
"All acronyms are defined in the Appendix.
} 
communication between biologists, oceanographers and engineers are critical to impart essential biological specifics, like natural history and capture logistics, of proposed MOOS to ensure successful operations. For example:

- In northern elephant seals Mirounga angustirostris, male and females differ in their migration patterns and behavior (e.g. male elephant seals forage in association with benthic features whereas females forage in association with large-scale ocean productivity patterns)[35]. Hence depending on what oceanographic question is at hand the gender of the animal must be deciphered before tagging.

- Additionally capture logistics differ according to species e.g. giant ocean sunfish (family Molidae) can be tagged by drifting slowly up to them and draping a net over their heads. In contrast tuna must be caught and ideally brought aboard a vessel to accurately place the tag. Differences in ease of handling must be considered as well.

Familiarity with differences between species and a set of realistic expectations will insure the successful use of MOOS. And while MOOS may not allow researchers ultimate control over a precise sampling path, they can offer access into nearly every region of the world's oceans. With that vast access comes precious local knowledge.

\section{Conclusion}

Animal tag data are currently being collected by investigators around the world. By initiating a synergistic relationship with the oceanographic community, biologists and engineers can optimize on-going tag development to ensure that data are made easily accessible for oceanographic applications.

In this time of growing environmental crisis for humanity, a system of global ocean monitoring is essential. No single country, agency or research facility can accomplish this monumental task on its own. Developing open highways of communication between all ocean research disciplines is critical in order to obtain the foundation of knowledge required to make reasonable climatic predictions. Biological autonomous sampling systems like MOOS have the potential to contribute vast amounts of oceanographic data in a cost-effective manner to compliment common physical databases. The oceanographic community can capitalize on the significant investment made by the biologic community in tag development and help devise the best means for utilizing incoming data from this powerful new research activity. Such a synergy will no doubt insure that the goals of all parties are efficiently and effectively realized.

\section{Acknowledgments}

The authors would like to thank George Boehlert for supplying his APBT manuscript, answering questions and for providing an exemplary model of what we hope will be the first of many similar works. 


\section{REFERENCES}

[1] Emery W. J., K. Cherkauer, B. Shannon, and R. W. Reynolds, 1997, Hull mounted sea surface temperatures from ships of opportunity. J. Atmos. Oceanic Technol., 14, 1237-1251.

[2] http://www.ise.bc.ca/theseus.html

[3] Arnold, G. and H. Dewar, 2001 Electronic tags in marine fisheries research: a thirty-year perspective. Results from JIMAR symposium on electronic tags, Honolulu Hawaii,2000, in press.

[4] Trefethen, P.S., 1956, Sonic equipment for tracking individual fish. Spec. Scientist Rep. U.S. Fish Wildlife Service, 179, $11 \mathrm{pp}$.

[5] Brill, R. W., G. H. Balazs, K. N. Holland, R. K. C. Chang, S. Sullivan, and J. C. George, 1995: Daily movements, habitat use, and submergence intervals or normal and tumor-bearing juvenile green turtles (Chelonia mydas L.) within a foraging area in the Hawaiian Islands. J. Exp. Mar. Biol. Ecol., 185, 203-218.

[6] Lutcavage, M. E., R. W. Brill, G. B. Skomal, B. C. Chase, J. L. Goldstein and J. Tutein, 2000, Tracking adult North Atlantic bluefin tuna (Thunnus thynnus) in the northwestern Atlantic using ultrasonic telemetry. Mar Biol., 137, 347-358.

Block, B. A., J. E. Keen, B. Castillo, H. Dewar, E. V. Freund, D. J. Marcinek, R. W. Brill and C. Farwell, 1997: Environmental preferences of yellowfin tuna (Thunnus albares) at the northern extent of its range. Mar. Biol., 130, 119-132.

Brill, R. W., D B. Holts, R. K. C. Chang, S. Sullivan, H. Dewar and F. G. Carey, 1993, Vertical and horizontal movements of striped marlin (Tetraptus audax) near the Hawaiian Islands, determined by ultrasonic telemetry, with simultaneous measurements of oceanic currents. Mar Biol. 117: 567-574.

Carey, F.G. and B. H. Robison, 1981, Daily patterns in the activity of swordfish, Xiphias gladius, observed by acoustic telemetry. Fish Bull. US, 79, 277-292.

[7] http://www.lotek.com

[8] http://www.vemco.com

[9] Inagake, D., H. Yamada,K. Segawa, M. Okazaki, A.Nitta, and T. Itoh, 2001, Migration of young bluefin tuna, Thunnus orientalis Temminck et Schlegel, through archival tagging experiments and its relation with oceanographic conditions in the western North Pacific. Bull. Nat. Res. Inst. Far Seas Fish., 38, 53-81.

Gunn, J., and J. Young, 2000, Environmental determinants of the movement and migration of juvenile southern bluefin tuna. In Hancock, D.A., Smith, D.C., and Koehn, J.D (eds.), Fish Movement and Migration, Australian Society for Fish Biology Workshop Proceedings, Bendigo, Victoria, September 1999. Australian Society for Fish Biology, Sydney, pp. 123-128.

Block, B.A., H. Dewar, T. Williams, E.D. Prince, C. Farwell, and D. Fudge, 1998, Archival tagging of Atlantic bluefin tuna (Thunnus thynnus thynnus). Mar. Tech. Soc. J., 32, 37-46.
Ishida, Y., A. Yano, M. Ban, and M. Ogura, 1998, Vertical movement of chum salmon, Oncorhynchus keta, in the western North Pacific Ocean as determined by a depthrecording archival tag. Nat. Res. Inst. Far Seas Fish., Salmon Report Series, 45, 199-211.

Metcalfe, J.D., G.P. Arnold, and B.H. Holford, 1994, The migratory behaviour of plaice in the North Sea as revealed by data storage tags. ICES Annual Science Conference, CM 1994/Mini:11,13 pp.

Metcalfe, J.D., B. H. Holford, and G. P. Arnold, 1993, Orientation of plaice (Pleuronectes platessa) in the open sea: evidence for the use of external directional clues. Mar. Biol. 117, 559-566.

[10] Hill, R. and M. Braun, 2001, Geolocation by LightLevel. The next step: Latitude. from JIMAR symposium on electronic tags, Honolulu HI, 2000, in press.

Welch, D.W., and Eveson, J.P. (1999). An assessment of light-based geoposition estimates from archival tags. Can. J. Fish. Aquat. Sci. 56, 1317-1327.

[11] Hill, R. and M. Braun, 2001,Geolocation by Light-Level. The next step: Latitude. from JIMAR symposium on electronic tags, Honolulu HI, 2000, in press.

Welch, D.W., and Eveson, J.P. (1999). An assessment of light-based geoposition estimates from archival tags. Can. J. Fish. Aquat. Sci. 56, 1317-1327.

[12] Le Boeuf ,B. J., D. E. Crocker, D. P. Costa, S. B. Blackwell, P. M. Webb, and D. S. Houser, 2000, Foraging ecology of northern elephant seals. Ecol. Monogr., 70, 353-382.

[13] Polovina , J. J., D. R. Kobayashi, D. M. Parker, M. P. Seki, and G. H. Balazs, 2000, Turtles on the edge: movement of loggerhead turtles (Caretta caretta) along oceanic fronts, spanning longline fishing grounds in the central North Pacific, 1997-1998. Fish Oceanogr. 9, 7182.

Eckert, S. A., 1999, Habitats and migratory pathways of the Pacific leatherback sea turtle. Final report to the national marine fisheries service, office of protected resources. Pp. 15. Hubbs Sea World Research Institute, San Diego Technical Report 99-290.

Eckert, S. A., 1998, Perspectives on the use of satellite telemetry and other electronic technologies for the study of marine turtles with reference to the first year long tracking of leatherback sea turtles. In $17^{\text {th }}$ Annual, Sea Turtle Symposium, vol. NOAA Tech Memo NMFSSEFSC-415 (ed. S.P. Epperly and J. Braun), pp. 294. U.S. Department of Commerce, NOAA, NMFS, NOAA Tech Memo NMFS-SEFSC-415, Orlando Florida.

[14] Eckert, S. A. and B. Stewart, 2001, Telemetry and satellite tracking of whale sharks, Rhincodon typus, in the Sea of Cortez, Mexico, and the North Pacific Ocean. Envir.Bio. Fish, 60, 299-308.

[15] Block, B.A., H. Dewar, S. Blackwell, T. Williams, E.D. Prince, C. Farwell, A. Boustany, A. Seitz, L. Teo and D. Fudge, D. Electronic tags reveal migratory movements, depth preferences and thermal biology of Atlantic bluefin tuna. Science, in press.

Lutcavage, M., R. Brill, J. Porter, P. Howey, E. Murray, A. Mendillo, W. Chaprales, M. Genovese, and T. Rollins, 
2000, Summary of pop-up satellite tagging of giant bluefin tuna in the joint US-Canadian program, Gulf of Maine and Canadian Atlantic. ICCAT, SCRS/00/95, 9 pp.

Lutcavage, M.E., R. W. Brill, G. B. Skomal, B. C. Chase and P.W. Howey, 1999, Results of pop-up satellite tagging of spawning size class fish in the Gulf of Maine: do North Atlantic bluefin tuna spawn in the mid-Atlantic? Can. J. Fish. Aquat. Sci. 56, 173-177.

Block, B.A., H. Dewar, C. Farwell and E.D. Prince,1998, A new satellite technology for tracking the movements of Atlantic bluefin tuna. Proc. Natl. Acad. Sci. USA 95, 9384-9389.

[16] Lutcavage, M. E., R. W.Brill, G. B. Skomal, B. C. Chase, and P. W. Howey, 1999: Results of pop-up satellite tagging of spawning size class fish in the Gulf of Maine: do North Atlantic bluefin tuna spawn in the mid-Atlantic? Can J. Fish. Aquat. Sci., 56, 173-177.

Block, B. A., J. E. Keen, B. Castillo, H. Dewar, E. V. Freund, D. J. Marcinek, R. W. Brill and C. Farwell, 1997, Environmental preferences of yellowfin tuna (Thunnus albares) at the northern extent of its range. Mar. Biol., 130, 119-132.

[17] Dewar, H. and M. Domeier unpublished data

[18] Holts D., NMFS, 1999, pers com

[19] Eckert, S. A. and B. Stewart, 2001, Telemetry and satellite tracking of whale sharks, Rhincodon typus, in the Sea of Cortez, Mexico, and the North Pacific Ocean. Envir.Bio. Fish, 60, 299-308.

[20] Thys T. and H. Dewar unpublished data

[21] Eckert, S. A., 1999, Habitats and migratory pathways of the Pacific leatherback sea turtle. Final report to the national marine fisheries service, office of protected resources. Pp. 15. Hubbs Sea World Research Institute, San Diego Technical Report 99-290.

[22] Dietz, R. and M.P. Heide-Jorgenson, 1995, Movements and swimming speed of narwhals, Monodon monoceros, equipped with satellite transmitters in Melville Bay, northwest Greenland. Can J of Zool. 73, 2106-2119.

Martin, A. R. and T. G. Smith and O.P. Cox, 1993, Studying the behavior and movements of high Arctic belugas with satellite telemetry. In Marine Mammals: Advances in Behavioral and Population Biology (ed. I.L. Boyd), Vol 66, pp. 195-210. Clarendon Press, Oxford.

[23] Le Boeuf, B. J., D. E. Crocker, D. P. Costa, S. B. Blackwell, P.M. Webb and D. S. Houser, 2000, Foraging ecology of northern elephant seals. Ecological Monographs 70, 353-382.

[24] Merrick, R. L., T.L. Loughlin, G. A. and R. Hill, 1994 Use of satellite-linked telemetry to study Stellar sea lion and northern fur seal foraging, Polar Research 13, 105114.

[25] Hamer, K.C. and N. H. Phillips, S. Wanless, M.P. Harris and A. G. Wood, 2000, Foraging ranges, diets and feeding locations of gannets Morus bassanus in the North Sea: evidence from satellite telemetry. Marine Ecology Progress Series 200, 257-264.

[26] Fedak, M. A. P. Lovell and S. M. Grant, 2001, Two approaches to compressing and interpreting time-depth information as collected by time-depth recorders and satellite-linked depth recorders. Marine Mammal Science 17: 94:110.;

Fedak, M. A. P. Lovell and B. J McConnell, 1996, MAMVIS: A marine mammal behavior visualization system. The Journal of Visualization and Computer Animation, 7, 141-147. www.smru.st-and.ac.uk

[27] Bonnell, M.L., B J. Le Boeuf, M. O. Pierson, D. H. Dettman, and G. D. Farrens. 1978 Pinnipeds of the Southern California Bight. Pp. 1-535 In Marine Mammal and Seabird Surveys of the Southern California Bight Area, 1975-1978. Bureau of Land Management, Depart of Interior Contract AA550-CT7-37, Government Printing Office, Washington.

[28] Block, B.A., H. Dewar, S. Blackwell, T. Williams, E.D. Prince, C. Farwell, A. Boustany, A. Seitz, L. Teo and D. Fudge, D. Electronic tags reveal migratory movements, depth preferences and thermal biology of Atlantic bluefin tuna. Science, in press.

Block, B.A., H. Dewar, C.Farwell, and E.D. Prince,1998, A new satellite technology for tracking the movements of Atlantic bluefin tuna. Proc. Natl. Acad. Sci. USA 95, 9384-9389.

[29] Banister, K. and A. Campbell ed., 1985, Encyclopedia of Aquatic Life, Facts on File Publications New York 349 pp.

[30] Klimley, A.P, S. B. Butler, D.R. Nelson, and A.T. Stull, 1988, Diel movements of scalloped hammerhead sharks, Sphyrna lewini Griffith and Smith, to and from a seamount in the Gulf of California. J. Fish Biol. 33, 751-761.

[31] Le Boeuf, B. J., D. E. Crocker, D. P. Costa, S. B. Blackwell, P. M. Webb, and D. S. Houser, 2000: Foraging ecology of northern elephant seals. Ecol. Monogr $70353-$ 382.

Boehlert, G.W., D. P. Costa, D. E. Crocker, P. Green, T. O'Brien, S. Levitus, and B. J. Le Boeuf, 2001, Autonomous Pinniped Environmental Samplers; Using Instrumented Animals as Oceanographic Data Collectors. J. Atmos. Oceanic Technol. in press.

[32] Boehlert, G.W., D. P. Costa, D. E. Crocker, P. Green, T. O'Brien, S. Levitus, and B. J. Le Boeuf, 2001, Autonomous Pinniped Environmental Samplers; Using Instrumented Animals as Oceanographic Data Collectors. J. Atmos. Oceanic Technol. in press.

[33] Ibid.

[34] Stone, G. J. Schubel and H. Tausig, 1999, Electronic Marine Animal Tagging: New Frontier in Ocean Science, Oceanography, 3, 24-27.

[35] Le Boeuf, B. J., D. E. Crocker, D. P. Costa, S. B. Blackwell, P. M. Webb, and D. S. Houser, 2000: Foraging ecology of northern elephant seals. Ecol. Monogr 70 353382.

\section{APPENDIX}

ABE Autonomous Benthic Explorer ALACE Autonomous drifting profiler APBT Autonomous Pinniped Bathythermograph APEX Autonomous Profiling Explorer ARGO Array for Real-Time Geostrophic Oceanography AUV Autonomous Underwater Vehicle 
AVHRR Advanced Very High Radiometer

CLIVAR Climate Variability and Predictability Experiment

GCOS Global Climate Observing System

GLOBEC Global Ocean Ecosystem Dynamics Program

GODAE Global Ocean Data Assimilation Project

GOOS Global Ocean Observing System

GPS Global Positioning System

GTSPP Global Temperature Salinity Profile Program

JGOFS Joint Global Ocean Flux Study

MODIS Moderate-resolution Imaging Spectroradiometer

MOOS Marine Organism Oceanic Sampler

NDBC National Data Buoy Center

NOAA National Oceanographic Atmospheric Association
NOPP National Oceanographic Partnership Program

OBIS Ocean Biogeographic Information System

POES Polar Oceanic Environmental Satellite

PSAT Pop-off Satellite Archival Tags

REMUS Remote Environmental Monitoring Units

SeaWiFS Sea Viewing Wide Field-of-view Sensor

SST Sea Surface Temperature

TOPEX Topography Experiment for Ocean Circulation

TTDR Time-Temperature-Depth Recorders

WOD World Oceanographic Database

XBT Expendable Bathythermograph 